the membrane during dialysis. The later onset, during dialysis, of reactions in coil-dialysed patients may be related to an increase in the bacterial population of the dialysate fluid and/or changes in the permeability of the membrane during dialysis.

Improved general health in home dialysis patients, together with less thorough data recording, may contribute to their lower incidence of reactions. The use of ion-exchange resins does not necessarily remove pyrogens from the water supply, and the resin itself may act as a reservoir of bacterial products. In our small group the use of a deionizer did not abolish pyrexial reactions. Biagini et al. (1970) reduced the incidence of reactions by pretreating the dialysate fluid with activated charcoal.

Prevention of reactions is otherwise limited to ensuring adequate sterilization of equipment and decontamination of the tap-water tanks used for soaking the dialysis membranes for the Kiil kidney. Treatment of the reactions is mainly symptomatic.

We wish to thank Mr. Neale and Mrs. Dunn, of the bacteriology department, St. James's Hospital, who examined the culture specimens; Mr. J. R. Roberts, of the Leeds City Water Works Department, for the tap-water analyses; and Sister P. A. Farrar and the nursing and technical staff of the regular dialysis unit for their untiring support and care of the patients.

\section{References}

Bennett, I. L., and Cluff, L. E. (1957) Pharmacological Reviews, 9, 427. Biagini, M., Rindi, P., Rizzo, G., and Giovanneti, S. (1970). Proceedings of the European Dialysis and Transplant Association, 7, 467.

Gazenfield-Gazit, E., and Eliahou, H. E. (1969). Israel fournal of Medical Sciences, 5, 1032 .

Jones, D. M., Tobin, B. M., Harlow, G. R., and Ralston, A. J. (1970), British Medical fournal, 3, 135

\title{
Abnormal Chemoreceptor Response to Hypoxia in Patients with Tabes Dorsalis
}

\author{
R. J. COURTENAY EVANS, M. K. BENSON, D. T. D. HUGHES
}

British Medical fournal, 1971, 1, 530-531

\section{Summary}

Nine patients with tabes dorsalis and one patient with diabetic autonomic neuropathy were subjected to hypoxia to test the integrity of their carotid chemoreceptors. Ventilation and pulse rate changes were monitored and compared with those of a group of normal subjects of comparable age and sex. Four patients had a completely negative response to hypoxia, and the changes in ventilation in the group of patients as a whole were significantly less than in the control subjects. The results indicate that some patients with autonomic denervation are unable to adjust their respiratory system in response to hypoxia.

\section{Introduction}

The carotid and aortic chemoreceptors respond to hypoxia in normal subjects by causing a reflex increase in pulse rate and ventilatory volume (Dripps and Comroe, 1947). These organs are sensitive primarily to lowering of arterial oxygen tension but do have less sensitivity to other stimuli. The reflex arc involved is innervated by visceral afferent nerves from the chemoreceptors to the brain stem, and then by sympathetic nerves to the heart and by somatic efferent nerves to the respiratory muscles.

The carotid and aortic baroreceptors are sensory receptors

London Hospital, London E1 1BB

R. J. COURTENAY EVANS, M.B., M.R.C.P. (Present appointment : Senior Medical Registrar, Addenbrooke's Hospital, Cambridge)

M. K. BENSON, M.B., M.R.C.P., Wellcome Research Fellow

D. T. D. HUGHES, B.SC., M.R.C.P., Senior Lecturer in Medicine for reflexes controlling blood pressure. Sharpey-Schafer (1956) showed that in fully developed tabes dorsalis the baroreceptor reflexes may be absent owing to the disease process affecting the afferent nerves involved in the reflex arc. In a later study (Sharpey-Schafer and Taylor, 1960) it was shown that in 31 out of 337 diabetics there were either defective or absent baroreceptcr reflexes. These abnormalities were associated with generalized autonomic denervation. Though there are several reports on the effects of autonomic denervation on the baroreceptor reflex, there is no report of the chemoreceptor reflexes in this condition. The results of surgical denervation of the carotid chemoreceptors, however, have been reported in two patients with asthma. After denervation they failed to respond to hypoxia (Holton and Wood, 1965). It was therefore decided to assess the effect of hypoxia on patients with tabes dorsalis and diabetic autonomic neuropathy.

\section{Methods}

Dripps and Comroe (1947), showed that the percentage of oxygen in inspired air has to be dropped to $10 \%$ before there is a constant pronounced increase in minute volume and pulse rate. The hypoxic stimulus used in the present study was therefore $10 \%$ oxygen and $90 \%$ nitrogen and ventilation was measured by the "bag in box" method (Donald and Christie, 1949). The alveolar carbon dioxide tension was not controlled in the present preliminary studies. Pulse rate was monitored by means of an electrocardiogram. Subjects were connected to the bag-box system and electrocardiograph. They became accustomed to breathing room air through the mouthpiece and valve until the tidal volume became constant. They were then turned on to the bag mixtures: room air $(20.9 \%$ oxygen) for three minutes and $10 \%$ oxygen for three minutes. The respiratory rate, tidal volume, minute volume, and pulse rate were all recorded. In normal subiects there was a rapid change in ventilation on switching to the low oxygen mixture. The ventilation in the second and third minutes was similar, and that during the third minute was measured and compared with the third minute breathing air. 
TABLE I-Responses in Normal Subjects

\begin{tabular}{|c|c|c|c|c|c|c|c|c|c|c|c|c|c|c|}
\hline \multirow[t]{2}{*}{$\begin{array}{l}\text { Subiect } \\
\text { No. }\end{array}$} & \multirow[t]{2}{*}{ Age } & \multirow[t]{2}{*}{ Sex } & \multicolumn{3}{|c|}{$\begin{array}{l}\text { Respiratory Rate } \\
\text { (resp/min) }\end{array}$} & \multicolumn{3}{|c|}{$\begin{array}{c}\text { Tidal Volume } \\
(\mathrm{ml})\end{array}$} & \multicolumn{3}{|c|}{$\underset{\text { (litres/min) }}{\text { Minute Volume }}$} & \multicolumn{3}{|c|}{$\begin{array}{l}\text { Pulse Rate } \\
\text { (beats/min) }\end{array}$} \\
\hline & & & $\begin{array}{c}\text { Room } \\
\text { Air }\end{array}$ & $10 \% \mathrm{O}_{2}$ & Change & $\begin{array}{c}\text { Room } \\
\text { Air }\end{array}$ & $10 \% \mathrm{O}_{2}$ & Change & $\begin{array}{c}\text { Room } \\
\text { Air }\end{array}$ & $10 \% \mathrm{O}_{2}$ & Change & $\begin{array}{c}\text { Room } \\
\text { Air }\end{array}$ & $10 \% \mathrm{O}_{2}$ & Change \\
\hline $\begin{array}{r}1 \\
2 \\
3 \\
4 \\
5 \\
6 \\
7 \\
8 \\
9 \\
10\end{array}$ & $\begin{array}{l}63 \\
62 \\
49 \\
64 \\
64 \\
69 \\
58 \\
62 \\
67 \\
63\end{array}$ & $\begin{array}{l}\text { M. } \\
\text { M. } \\
\text { M. } \\
\text { M. } \\
\text { F. } \\
\text { F. } \\
\text { F. } \\
\text { F. } \\
\text { F. } \\
\text { F. }\end{array}$ & $\begin{array}{r}10 \\
9 \\
12 \\
18 \\
12 \\
12 \\
12 \\
12 \\
16 \\
14\end{array}$ & $\begin{array}{r}12 \\
9 \\
11 \\
17 \\
13 \\
13 \\
14 \\
13 \\
18 \\
15\end{array}$ & $\begin{array}{r}2 \\
0 \\
-1 \\
-1 \\
1 \\
1 \\
2 \\
1 \\
2 \\
1\end{array}$ & $\begin{array}{l}720 \\
700 \\
460 \\
425 \\
500 \\
400 \\
500 \\
600 \\
325 \\
600\end{array}$ & $\begin{array}{r}1,200 \\
1,200 \\
750 \\
900 \\
550 \\
500 \\
500 \\
750 \\
450 \\
650\end{array}$ & $\begin{array}{r}480 \\
500 \\
290 \\
475 \\
50 \\
100 \\
0 \\
150 \\
125 \\
50\end{array}$ & $\begin{array}{l}7 \cdot 2 \\
6.3 \\
5.5 \\
7.65 \\
6 \cdot 0 \\
4 \cdot 8 \\
6.0 \\
7 \cdot 2 \\
5 \cdot 2 \\
8 \cdot 4\end{array}$ & $\begin{array}{c}14 \cdot 4 \\
10 \cdot 8 \\
8 \cdot 25 \\
15 \cdot 3 \\
7 \cdot 15 \\
6 \cdot 5 \\
7 \cdot 0 \\
9 \cdot 75 \\
8 \cdot 1 \\
9 \cdot 75\end{array}$ & $\begin{array}{l}7 \cdot 2 \\
4.5 \\
2.75 \\
7.65 \\
1.15 \\
1.7 \\
1.0 \\
2.55 \\
2.9 \\
1 \cdot 35\end{array}$ & $\begin{array}{l}70 \\
84 \\
72 \\
68 \\
64 \\
72 \\
74 \\
80 \\
76 \\
78\end{array}$ & $\begin{array}{l}78 \\
90 \\
88 \\
78 \\
78 \\
80 \\
84 \\
92 \\
88 \\
92\end{array}$ & $\begin{array}{r}8 \\
6 \\
16 \\
10 \\
14 \\
8 \\
10 \\
12 \\
12 \\
14\end{array}$ \\
\hline \multicolumn{2}{|c|}{ Mean $62 \cdot 1$} & & $12 \cdot 7$ & 13.5 & 0.8 & 523 & 745 & 222 & 6.425 & $9 \cdot 70$ & $3 \cdot 275$ & $73 \cdot 8$ & 84.8 & 11 \\
\hline
\end{tabular}

TABLE II-Results in Patients with Tabes Dorsalis

\begin{tabular}{|c|c|c|c|c|c|c|c|c|c|c|c|c|c|c|}
\hline \multirow{2}{*}{$\begin{array}{l}\text { Case } \\
\text { No. }\end{array}$} & \multirow{2}{*}{ Age } & \multirow{2}{*}{ Sex } & \multicolumn{3}{|c|}{$\begin{array}{l}\text { Respiratory Rate } \\
\text { (resp/min) }\end{array}$} & \multicolumn{3}{|c|}{$\begin{array}{l}\text { Tidal Volume } \\
(\mathrm{ml})\end{array}$} & \multicolumn{3}{|c|}{$\underset{\text { (litres/min) }}{\text { Minute Volume }}$} & \multicolumn{3}{|c|}{$\begin{array}{l}\text { Pulse Rate } \\
\text { (beats/min) }\end{array}$} \\
\hline & & & $\begin{array}{c}\text { Room } \\
\text { Air }\end{array}$ & $10 \% \mathrm{O}_{2}$ & Change & $\begin{array}{c}\text { Room } \\
\text { Air }\end{array}$ & $10 \% \mathrm{O}_{3}$ & Change & $\begin{array}{c}\text { Room } \\
\text { Air }\end{array}$ & $10 \% O$ & Change & $\begin{array}{c}\text { Room } \\
\text { Air }\end{array}$ & $10 \% \mathrm{O}_{2}$ & Change \\
\hline $\begin{array}{c}1 \\
2 * \\
3 \\
4 \\
5 \\
6 \\
7 \\
8 \\
9 \\
10\end{array}$ & $\begin{array}{l}67 \\
59 \\
62 \\
52 \\
66 \\
68 \\
63 \\
45 \\
65 \\
63\end{array}$ & $\begin{array}{l}\text { M. } \\
\text { F. } \\
\text { F. } \\
\text { M. } \\
\text { M. } \\
\text { F. } \\
\text { F. } \\
\text { M. } \\
\text { F. } \\
\text { F. }\end{array}$ & $\begin{array}{l}10 \\
19 \\
20 \\
18 \\
23 \\
11 \\
17 \\
18 \\
22 \\
20\end{array}$ & $\begin{array}{l}10 \\
19 \\
20 \\
18 \\
28 \\
11 \\
17 \\
18 \\
19 \\
21\end{array}$ & $\begin{array}{r}0 \\
0 \\
0 \\
0 \\
5 \\
0 \\
0 \\
0 \\
-3 \\
1\end{array}$ & $\begin{array}{r}1,100 \\
250 \\
550 \\
300 \\
500 \\
550 \\
475 \\
650 \\
525 \\
375\end{array}$ & $\begin{array}{r}1,100 \\
250 \\
500 \\
450 \\
550 \\
650 \\
600 \\
750 \\
600 \\
400\end{array}$ & $\begin{array}{r}0 \\
0 \\
-50 \\
150 \\
50 \\
100 \\
125 \\
100 \\
75 \\
25\end{array}$ & $\begin{array}{c}11.0 \\
4.75 \\
11.0 \\
5.4 \\
11.5 \\
6.05 \\
8.1 \\
11.7 \\
11.5 \\
7.5\end{array}$ & $\begin{array}{c}11.0 \\
4.75 \\
10.0 \\
8.1 \\
15.4 \\
7.15 \\
10.02 \\
13.5 \\
11.5 \\
8.4\end{array}$ & $\begin{array}{l}0 \\
0 \\
-1.0 \\
2.7 \\
3.9 \\
1.1 \\
1.92 \\
1.8 \\
0 \\
0.9\end{array}$ & $\begin{array}{c}88 \\
88 \\
78 \\
68 \\
70 \\
68 \\
90 \\
96 \\
132 \dagger \\
92\end{array}$ & $\begin{array}{c}88 \\
88 \\
78 \\
88 \\
80 \\
80 \\
104 \\
100 \\
132 \dagger \\
100\end{array}$ & $\begin{array}{r}0 \\
0 \\
0 \\
20 \\
10 \\
12 \\
14 \\
4 \\
0 \\
8\end{array}$ \\
\hline \multicolumn{2}{|c|}{ Mean 61} & & $17 \cdot 8$ & $18 \cdot 1$ & 0.3 & $527 \cdot 5$ & 585 & $57 \cdot 5$ & $8 \cdot 85$ & 9.982 & $1 \cdot 132$ & 87 & 93.8 & $6 \cdot 8$ \\
\hline
\end{tabular}

-Diabetic neuropathy.

Diabetic neuropathy.
Patient with supraventricular tachycardia.

TABLE IIJ-Response to Hypoxia in Controls and Patients

\begin{tabular}{|c|c|c|c|c|c|c|c|c|c|c|c|c|}
\hline & & & & & \multicolumn{2}{|c|}{$\begin{array}{l}\text { Respiratory Rate } \\
\text { (resp/min) }\end{array}$} & \multicolumn{2}{|c|}{$\begin{array}{l}\text { Tidal Volume } \\
(\mathrm{ml})\end{array}$} & \multicolumn{2}{|c|}{$\underset{\text { (litres/min) }}{\text { Minute Volume }}$} & \multicolumn{2}{|c|}{$\begin{array}{l}\text { Pulse Rate } \\
\text { (beats/min) }\end{array}$} \\
\hline & & & & & Controls & Tabes & Controls & Tabes & Controls & Tabes & Controls & Tabes \\
\hline Change after $10 \%$ oxygen & .. & . & . & . & +0.8 & +0.3 & $+222 \cdot 0$ & $+57 \cdot 5$ & $+3 \cdot 275$ & $+1 \cdot 30$ & $+11 \cdot 0$ & +6.8 \\
\hline Significance of change & .. & . & .. & . & $P<0.05$ & N.S. & $P<0.005$ & $P<0.01$ & $P<0.0025$ & $P<0.025$ & $P<0.0005$ & $P<0.01$ \\
\hline Difference between groups & $\ldots$ & $\cdots$ & $\ldots$ & $\cdots$ & \multicolumn{2}{|c|}{ N.S. } & \multicolumn{2}{|c|}{$P<0.0125$} & \multicolumn{2}{|c|}{$P<0.025$} & \multicolumn{2}{|c|}{ N.S. } \\
\hline
\end{tabular}

\section{Results}

Ten normal subjects were tested and the results are shown in Table I. A significant increase in ventilation was noted, comparable to the results of Dripps and Comroe (1947). This was mainly due to an increase in tidal volume. The pulse rate increased significantly.

Ten patients were tested, nine with tabes dorsalis and one with diabetic neuropathy. The results are shown in Table II. Three tabetics (Cases 1, 3, and 9) and the diabetic patient showed no response to hypoxia. In the remainder the respons was variable. The difference in ventilatory response between patient and control groups was statistically significant, the former responding less (Table III). Though the mean increasc in pulse rate was less in the tabetic group, this did not reach statistical significance.

\section{Discussion}

These results confirmed that normal subjects respond to hypoxia by increasing pulse rate and ventilation. It would also seem from the small group of patients tested so far that some with suspected autonomic denervation have negative chemoreceptor reflexes. Among the tabetic subjects the results varied from a complete absence of response to a normal one, but there was a statistically significant difference in ventilatory response between the patients and the controls. It is therefore suggested that reflexes from the chemoreceptors as well as from the baroreceptors may be impaired in tabes and diabetic poripheral neuropathy due to disease of the afferent nerves. These preliminary findings suggest that further work using more refined methods for measuring ventilation and maintaining a constant $\mathrm{PCO}_{2}$ and $\mathrm{PO}_{2}$ would be worth while.

\section{References}

Donald, K. W., and Christie, R. V. (1949). Clinical Science, 8, 21. Dripps, R. D., and Comroe, J. H. (1947). American Fournal of Physiology,

149, 277.
Holton, P., and Wood, I. B. (1965). Fournal of Physiology, 181, 365.

Sharpey-Schafer, E. P. (1956). Fournal of Phvsiologv, 134, 1.

Sharpey-Schafer, E. P., and Tavlor, P. J. (1960). Lancet, 1, 559. 